\title{
PENGARUH PENDAPATAN ASLI DAERAH DAN DANA PERIMBANGAN TERHADAP BELANJA DAERAH PADA PEMERINTAH DAERAH KABUPATEN KEBUMEN TAHUN 2009-2018
}

\author{
Wiwit Yulia Prestika, Aris Susetyo \\ Sekolah Tinggi Ilmu Ekonomi Putra Bangsa \\ prestikae@gmail.com
}

\begin{abstract}
Abstrak
Penelitian ini bertujuan untuk menganalisis pengaruh Pendapatan Asli Daerah (PAD) terhadap Belanja Daerah pada pemerintah daerah Kabupaten Kebumen; pengaruh Dana Perimbangan terhadap Belanja Daerah pada pemerintah daerah Kabupaten Kebumen; serta pengaruh Pendapatan Asli Daerah (PAD) dan Dana Perimbangan terhadap Belanja Daerah pada pemerintah daerah Kabupaten Kebumen. Penelitian ini menggunakan data sekunder yang berupa Laporan Realisasi Anggaran Pendapatan dan Belanja Daerah tahun 2009 sampai dengan tahun 2018. Pengujian hipotesis dalam penelitian ini menggunakan regresi linier berganda dengan bantuan SPSS 16 for Windows, dengan pengujian berupa uji t, uji F, dan uji koefisien determinasi. Hasil penelitian secara parsial menunjukkan bahwa Pendapatan Asli Daerah dan Dana Perimbangan berpengaruh signifikan terhadap Belanja Daerah. Sedangkan hasil uji hipotesis secara simultan menunjukkan bahwa terdapat pengaruh yang signifikan antara Pendapatan Asli Daerah dan Dana Perimbangan terhadap Belanja Daerah Kabupaten Kebumen.
\end{abstract}

Kata kunci: Pendapatan Asli Daerah, Dana Perimbangan, Belanja Daerah

\begin{abstract}
This study aimed to analyze the effect of Regional Original Income on Regional Expenditures on the regional government of Kebumen Regency; the effect of the Balancing Fund on Regional Expenditure on the regional government of Kebumen Regency; and the effect of Regional Original Income and Balancing Funds on Regional Expenditures on the regional government of Kebumen Regency. This study used secondary data in the form of Realization of Regional Revenue and Expenditure Budget Report 2009 to 2018. The hypothesis in this study was tested multiple linear regression with the help of SPSS 16 for Windows, with testing in the form of $t$ test, $F$ test, and test coefficient of determination. The results of the study showed that the Regional Original Income and Balancing Funds have a significant effect on Regional Expenditures. While the results of simultaneous hypothesis testing indicate that there was a significant influence between Regional Original Revenue and Balancing Funds for Regional Expenditures in Kebumen Regency.
\end{abstract}

Keywords: Regional Original Income, Balancing Funds, Regional Expenditure 


\section{PENGARUH PENDAPATAN ASLI DAERAH DAN DANA PERIMBANGAN TERHADAP BELANJA DAERAH PADA PEMERINTAH DAERAH KABUPATEN KEBUMEN TAHUN 2009-2018}

\section{PENDAHULUAN}

Berlangsungnya era reformasi di Indonesia pada tahun 1998 berdampak pada gencarnya tuntutan yang dilakukan masyarakat agar pemerintah segera melakukan reformasi birokrasi supaya terselenggaranya pemerintahan yang bersih dan menjunjung tinggi asas keterbukaan. Pelaksanaan reformasi birokrasi diperkuat dengan diberlakukannya Undang-Undang Nomor 23 Tahun 2004 tentang Pemerintah Daerah dan UndangUndang Nomor 33 Tahun 2004 tentang Perimbangan Keuangan antara Pemerintah Pusat dan Pemerintah Daerah. Hal ini mendorong terjadinya proses peralihan dari sistem dekonsentrasi ke sistem desentralisasi yang disebut dengan otonomi. Otonomi daerah merupakan hak, wewenang, dan kewajiban daerah otonom untuk mengatur dan mengurus sendiri urusan pemerintah dan kepentingan masyarakat setempat sesuai dengan peraturan perundangan-undangan.

Pelaksanaan otonomi daerah dan desentralisasi fiskal menjadikan pemerintah daerah sebagai titik sentral dalam penyelenggaraan pemerintahan dan pembangunan dengan mengedepankan otonomi luas, nyata, dan bertanggung jawab di daerah secara proporsional yang diwujudkan dengan pengaturan, pemberian, dan pemanfaatan sumber daya nasional yang terkendali serta perimbangan keuangan pemerintah pusat dan daerah. Samad dan Iyan (2013) dalam Wati dan Fajar (2017: 60) menyatakan bahwa pelaksanaan otonomi daerah akan membawa suatu konsekuensi logis, bahwa tiap daerah harus berkemampuan untuk memberdayakan dirinya sendiri, baik dalam kepentingan ekonomi, pembinaan sosial kemasyarakatan, dan pemenuhan kebutuhan untuk membangun daerahnya serta dapat melaksanakan peningkatan pelayanan kepada masyarakat.

Pelaksanaan otonomi daerah tersebut tentu saja memerlukan sumber pendanaan yang cukup besar, sehingga penyelenggaraan fungsi pemerintahan daerah akan terasa sangat optimal apabila diikuti dengan sumber-sumber penerimaan yang cukup terhadap daerah. Sumber penerimaan suatu daerah dari sisi pendapatan yaitu daerah diberi kewenangan untuk memungut pajak dan retribusi daerah berdasarkan peraturan daerah yang ada, sedangkan dari sisi pengeluaran, pemerintah daerah sesuai dengan fungsinya sebagai pemberi pelayanan kepada masyarakat di daerah diberi kebebasan untuk mengelola dan membelanjakan penerimaan daerah yang dituangkan dalam Anggaran Pendapatan dan Belanja Daerah (APBD). Anggaran Pendapatan dan Belanja Daerah (APBD) merupakan rencana keuangan tahunan pemerintah daerah yang dibahas dan disetujui bersama antara pemerintah daerah dan Dewan Perwakilan Rakyat Daerah (DPRD) kemudian ditetapkan dalam peraturan daerah. Sumber penerimaan yang merupakan modal dasar pemerintah daerah yaitu Pendapatan Asli Daerah (PAD). Indikator penting keberhasilan kemampuan keuangan daerah tercermin dalam kemampuan daerah dalam menggali PAD. Selain itu, di sisi sumber penerimaan atau pendapatan terdapat Dana Perimbangan yang merupakan komponen terbesar dalam alokasi transfer ke daerah, adanya Dana Perimbangan sangat mendukung pelaksanaan desentralisasi fiskal.

Pesatnya perkembangan zaman, menuntut pemerintah daerah untuk melakukan pembangunan yang besar sehingga menyebabkan Belanja Daerah semakin meningkat pula. Belanja daerah juga merupakan tolak ukur keberhasilan pelaksanaan kewenangan daerah. Fenomena umum yang terjadi di sebagian besar pemerintah daerah di Indonesia di bidang keuangan daerah adalah peranan atau kontribusi PAD yang relatif lebih kecil dibandingkan dengan Dana Perimbangan dari pemerintah pusat yang relatif besar dalam struktur APBD. Sehingga, pemerintah daerah lebih menggantungkan diri pada Dana Perimbangan guna mendorong berlangsungnya pemerintah daerah otonom dalam melakukan belanja daerah yang lebih besar. Tabel I.1 berikut menunjukkan realisasi besarnya Pendapatan Asli Daerah, dana perimbangan, lain-lain pendapatan daerah yang sah dan belanja daerah pada Kebupaten Kebumen tahun 2015-2017.

Tabel I.1

Realisasi PAD, Dana Perimbangan, Lain-Lain Pendapatan Daerah yang Sah dan Belanja Daerah Kabupaten Kebumen Tahun 2015-2017

\begin{tabular}{lccc} 
& 2015 & 2016 & \multicolumn{1}{c}{2017} \\
\hline PAD & 245.159 .255 .421 & 291.016 .321 .703 & 443.608 .862 .461 \\
Dana & 1.343 .315 .952 .370 & 1.779 .771 .732 .786 & 1.712 .419 .381 .173 \\
$\begin{array}{l}\text { Perimbangan } \\
\text { Lain-Lain }\end{array}$ & & & \\
$\begin{array}{l}\text { Pendapatan } \\
\text { Daerah yang }\end{array}$ & 21.148 .531 .000 & 3.030 .221 .000 & 5.214 .000 .000 \\
Sah & & & \\
Belanja & 2.033 .106 .110 .204 & 2.283 .531 .796 .631 & 2.113 .132 .464 .285 \\
Daerah & & & \\
\hline Sumber: BPKAD Kabupaten Kebumen & &
\end{tabular}

Berdasarkan tabel I.1 dapat diketahui bahwa ada tiga komponen pendapatan daerah dalam struktur Anggaran Pendapatan dan Belanja Daerah (APBD) berupa Pendapatan Asli Daerah (PAD), Dana Perimbangan, dan Lain-Lain Pendapatan Daerah yang Sah dalam membiayai belanja daerahnya. Terlihat jelas bahwa peranan Dana Perimbangan sangat besar sebagai penyokong Pendapatan Asli Daerah (PAD) dan LainLain Pendapatan Daerah yang Sah di sisi pendapatan daerah pemerintah daerah Kabupaten Kebumen untuk meningkatkan pelayanan publik. Pendapatan Asli Daerah (PAD) dan Dana Perimbangan merupakan pendapatan daerah yang tentunya digunakan oleh pemerintah daerah untuk membiayai Belanja Daerah untuk meningkatkan pelayanan publik pemerintah daerah, belanja daerah dipergunakan dalam rangka mendanai pelaksanaan urusan pemerintah dalam menjalankan urusannya. 


\section{PENGARUH PENDAPATAN ASLI DAERAH DAN DANA PERIMBANGAN TERHADAP BELANJA DAERAH PADA PEMERINTAH DAERAH KABUPATEN KEBUMEN TAHUN 2009-2018}

Berdasarkan latar belakang tersebut, maka penulis tertarik untuk menganalisa pengaruh Pendapatan Asli Daerah dan Dana Perimbangan terhadap Belanja Daerah pada Pemerintah Daerah Kabupaten Kebumen tahun 2009-2018.

\section{Rumusan Masalah :}

Berdasarkan latar belakang yang telah diuraikan di atas, dapat dirumuskan permasalahan sebagai berikut:

1. Apakah Pendapatan Asli Daerah (PAD) memiliki pengaruh terhadap Belanja Daerah pada Pemerintah Daerah Kabupaten Kebumen tahun 2009-2018?

2. Apakah Dana Perimbangan memiliki pengaruh terhadap Belanja Daerah pada Pemerintah Daerah Kabupaten Kebumen tahun 2009-2018?

3. Apakah Pendapatan Asli Daerah (PAD) dan Dana Perimbangan memiliki pengaruh terhadap Belanja Daerah pada Pemerintah Daerah Kabupaten Kebumen tahun 2009-2018?

\section{TINJAUAN PUSTAKA}

\section{Landasan Teori}

\section{Pendapatan Asli Daerah}

Berdasarkan Undang-Undang Nomor 33 Tahun 2004 tentang Perimbangan Keuangan antara Pemerintah Pusat dan Pemerintah Daerah, Pendapatan Asli Daerah (PAD) merupakan pendapatan daerah yang bersumber dari hasil pajak daerah, hasil retribusi daerah, hasil pengelolaan kekayaan daerah yang dipisahkan, dan lain-lain pendapatan asli daerah yang sah, yang bertujuan untuk memberikan keleluasaan kepada daerah dalam menggali pendanaan dalam pelaksanaan otonomi daerah sebagai perwujudan asas desentralisasi.

Pendapatan Asli Daerah merupakan wujud representasi kemampuan pemerintah daerah dalam menggali potensi yang dimiliki, sehingga pemerintah daerah diberi keleluasaan untuk mendanai pelaksanaan otonomi daerah sesuai dengan potensi daerah yang sejalan dengan prinsip otonomi daerah dan asas desentralisasi. Semakin besar Pendapatan Asli Daerah (PAD) yang dihasilkan, maka semakin mandiri pula daerah tersebut secara financial dalam membiayai pemerintahannya dan memberikan pelayanan kepada masyarakat, karena peningkatan kemandirian daerah sangat erat kaitannya dengan kemampuan daerah dalam mengelola Pendapatan Asli Daerah (PAD).

Besarnya penerimaan Pendapatan Asli Daerah (PAD) dijadikan sebagai tolak ukur keberhasilan dari pelaksanaan otonomi suatu daerah. Hal tersebut menunjukkan betapa pentingnya peningkatan PAD dalam penyelenggaraan pemerintahan, pembangunan, dan pelayanan publik di suatu daerah.

\section{Dana Perimbangan}

Dana perimbangan merupakan sumber pendapatan daerah yang berasal dari Anggaran Pendapatan dan Belanja Negara (APBN) untuk mendukung pelaksanaan kewenangan pemerintah daerah dalam mencapai tujuan pemberian otonomi kepada daerah, terutama peningkatan pelayanan dan kesejahteraan masyarakat yang semakin baik (Widjaja, 2002).

Berdasarkan Undang-Undang Nomor 33 Tahun 2004 tersebut, dijelaskan mengenai perincian pendapatan yang termasuk ke dalam dana perimbangan pemerintah pusat dan pemerintah daerah yang bersumber dari Anggaran Pendapatan dan Belanja Negara (APBN) yaitu terdiri dari sebagai berikut:

a. Dana Bagi Hasil

Menurut Undang-Undang Nomor 33 Tahun 2004 Pasal 1 Ayat 20, menyatakan bahwa Dana Bagi Hasil (DBH) merupakan dana yang bersumber dari Anggaran Pendapatan dan Belanja Nasional (APBN) yang dialokasikan kepada daerah berdasarkan angka persentase untuk mendanai kebutuhan daerah dalam rangka pelaksanaan desentralisasi. Terdapat dua jenis sumber penerimaan Dana Bagi Hasil, yaitu Dana Bagi Hasil Pajak dan Dana Bagi Hasil Non Pajak. Dana Bagi Hasil Pajak bersumber dari Pajak Bumi dan Bangunan (PBB), Bea Perolehan Hak atas Tanah dan Bangunan (BPHTB), Pajak Penghasilan (PPh) Pasal 25, PPh Pasal 29 Wajib Pajak Orang Pribadi Dalam Negeri, dan PPh Pasal 21. Sedangkan penerimaan Dana Bagi Hasil Non Pajak berasal dari sumber daya alam yang bersumber dari Kehutanan, Pertambangan Umum, Perikanan, Pertambangan Minyak Bumi, Pertambangan Gas Bumi, dan Pertambangan Panas Bumi.

b. Dana Alokasi Umum

Menurut Syarifin dan Jubaedah (2005: 108)

Dana Alokasi Umum adalah dana yang bersumber dari pendapatan APBN yang dialokasikan kepada daerah, dengan tujuan pemerataan kemampuan keuangan antar daerah, untuk mendanai kebutuhan daerah dalam rangka pelaksanaan desentralisasi. Dana Alokasi Umum (DAU) bertujuan untuk pemerataan dan mengurangi ketimpangan kemampuan keuangan antara daerah melalui penerapan formula yang mempertimbangkan kebutuhan dan potensi daerah. DAU suatu daerah ditentukan atas besar kecilnya celah fiskal suatu daerah, yang merupakan selisih antara kebutuhan daerah dan potensi daerah. Dana Alokasi Umum (DAU) digunakan untuk menutup celah yang terjadi karena kebutuhan daerah melebihi dari potensi penerimaan daerah yang ada (Banga, 2017: 101). 


\section{PENGARUH PENDAPATAN ASLI DAERAH DAN DANA PERIMBANGAN TERHADAP BELANJA DAERAH PADA PEMERINTAH DAERAH KABUPATEN KEBUMEN TAHUN 2009-2018}

\section{c. Dana Alokasi Khusus}

Menurut Undang-Undang Nomor 33 Tahun 2004, tentang Perimbangan Keuangan Pemerintah Pusat dan Pemerintah Daerah, pengertian Dana Alokasi Khusus (DAK) merupakan dana yang bersumber dari pendapatan APBN yang dialokasikan kepada daerah tertentu dengan tujuan untuk membantu mendanai kegiatan khusus yang merupakan urusan daerah dan sesuai dengan prioritas nasional. Menurut Yani (2008: 172), Dana Alokasi Khusus (DAK) merupakan dana yang dialokasikan untuk membantu daerah mendanai kebutuhan fisik sarana dan prasarana yang merupakan prioritas nasional di bidang pendidikan, kesehatan, infrastruktur (jala, irigasi, dan air bersih), kelautan dan perikanan, pertanian, prasarana pemerintah daerah, serta lingkungan hidup.

Berdasarkan pengertian Dana Alokasi Khusus (DAK) di atas maka dapat diketahui bahwa Dana Alokasi Khusus (DAK) merupakan salah satu mekanisme transfer keuangan pemerintah pusat ke daerah yang bertujuan antara lain untuk meningkatkan penyediaan sarana dan prasarana fisik daerah sesuai prioritas nasional serta mengurangi kesenjangan laju pertumbuhan antar daerah dan pelayanan antar bidang.

\section{Belanja Daerah}

Belanja daerah diatur dalam Undang-Undang Nomor 9 Tahun 2015 tentang Pemerintah Daerah, menyatakan bahwa belanja daerah adalah semua kewajiban daerah yang diakui sebagai pengurangan nilai kekayaan bersih dalam periode tahun anggaran yang bersangkutan. Belanja daerah atau yang dikenal dengan pengeluaran pemerintahan daerah dalam Anggaran Pendapatan dan Belanja Daerah (APBD), merupakan salah satu faktor pendorong pertumbuhan ekonomi daerah. Sehingga belanja daerah dikenal sebagai salah satu instrumen kebijakan fiskal yang dilakukan pemerintah daerah, di samping pos pendapatan pemerintahan daerah. Semakin besar belanja daerah maka akan makin meningkatkan kegiatan perekonomian daerah.

Halim (2001: 199) menyatakan bahwa pengeluaran daerah adalah semua pengeluaran kas daerah selama periode tahun anggaran bersangkutan yang mengurangi kekayaan pemerintah daerah. Menurut Anggara (2016) dalam Banga (2017: 102), setiap tahun kebutuhan daerah semakin meningkat. Konsekuensi yang terjadi yaitu dana yang diperlukan untuk belanja daerah semakin meningkat pula. Namun demikian, pada akhirnya besarnya belanja yang dapat digunakan oleh daerah setiap tahunnya sangat ditentukan oleh kemampuan pendapatan daerah.

\section{Kerangka Pemikiran}

Berdasarkan latar belakang masalah, kajian pustaka dan penelitian terdahulu yang relevan, maka dapat dibuat kerangka pemikiran sebagai berikut:

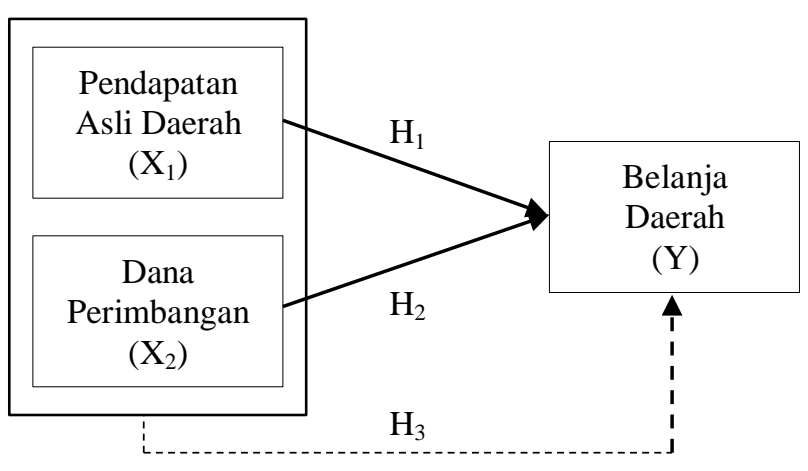

Gambar II.1 Model Kerangka Pemikiran

\section{Hubungan antara Masing-Masing Variabel}

\section{Pengaruh Pendapatan Asli Daerah dengan} Belanja Daerah

Pendapatan Asli Daerah (PAD) merupakan sumber pendapatan penting bagi sebuah daerah dalam memenuhi belanjanya. Dan Pendapatan Asli Daerah (PAD) ini sekaligus dapat menujukan tingkat kemandirian suatu daerah. Semakin banyak Pendapatan Asli Daerah (PAD) yang didapat semakin memungkinkan daerah tersebut untuk memenuhi kebutuhan belanjanya sendiri tanpa harus tergantung pada Pemerintah Pusat, yang berarti ini menunjukan bahwa Pemerintah Daerah tersebut telah mampu untuk mandiri, dan begitu juga sebaliknya. PAD memiliki peran yang cukup signifikan dalam menentukan kemampuan daerah untuk melakukan aktivitas pemerintah dan programprogram pembangunan daerah. Pemerintah mempunyai kewajiban untuk meningkatkan taraf kesejahteraan rakyat serta menjaga dan memelihara ketentraman dan ketertiban masyarakat. Jadi, PAD berpengaruh terhadap belanja daerah.

\section{Pengaruh Dana Perimbangan dengan Belanja Daerah}

Dana perimbangan merupakan dana yang bersumber dari pendapatan APBN yang dialokasikan kepada daerah untuk mendanai kebutuhan daerah dalam rangka pelaksanaan desentralisasi (UndangUndang Nomor 33 Tahun 2004 Pasal 1 Ayat 18). Dana perimbangan merupakan dana alokasi dari pemerintah pusat yang berfungsi untuk mendorong otonomi daerah, bahkan bagi beberapa daerah yang memiliki Pendapatan Asli Daerah yang relatif kecil, jalannya roda pemerintahan akan bergantung pada tersedianya dana perimbangan.

Pada penelitian Wulandari (2014), mengemukakan hasil penelitiannya yang menyatakan bahwa dana perimbangan berpengaruh 


\section{PENGARUH PENDAPATAN ASLI DAERAH DAN DANA PERIMBANGAN TERHADAP BELANJA DAERAH PADA PEMERINTAH DAERAH KABUPATEN KEBUMEN TAHUN 2009-2018}

signifikan terhadap belanja daerah, artinya jika dana perimbangan meningkat maka belanja daerah juga meningkat.

\section{Perumusan Hipotesis}

Berdasarkan uraian di atas, maka hipotesis yang diajukan dalam penelitian ini adalah:

$\mathrm{H}_{1}$ : Pendapatan Asli Daerah (PAD) berpengaruh signifikan terhadap Belanja Daerah

$\mathrm{H}_{2}$ : Dana Perimbangan berpengaruh signifikan terhadap Belanja Daerah

$\mathrm{H}_{3}$ : Pendapatan Asli Daerah (PAD) dan Dana Perimbangan berpengaruh signifikan terhadap Belanja Daerah

\section{METODOLOGI PENELITIAN}

\section{Jenis Penelitian}

Jenis penelitian ini merupakan penelitian deskriptif kuantitatif yaitu mendeskripsikan hasil pengolahan data angka berupa rasio keuangan yang terdapat dalam laporan realisasi Anggaran Pendapatan dan Belanja Daerah Pemerintah Daerah Kabupaten Kebumen untuk dianalisis pengaruhnya kemudian ditarik kesimpulan berupa kata-kata berdasarkan kriteria yang telah ditetapkan.

\section{Subjek dan Objek Penelitian}

Subjek penelitian merupakan sesuatu yang sangat penting kedudukannya di dalam penelitian, subjek penelitian harus ditata sebelum penelitian siap untuk mengumpulkan data (Arikunto, 2010: 152). Subjek penelitian dalam penelitian ini adalah Badan Pengelolaan Keuangan dan Aset Daerah (BPKAD) Kabupaten Kebumen.

Sedangkan dalam penelitian ini, yang menjadi objek penelitian adalah Laporan Realisasi Anggaran Pendapatan dan Belanja Daerah (APBD) Pemerintah Daerah Kabupaten Kebumen tahun 2009 sampai dengan tahun 2018.

\section{Definisi Operasional Variabel}

Definisi operasional yang digunakan dalam penelitian ini dapat dilihat sebagai berikut:

1. Variabel Dependen (Y)

Variabel dependen adalah variabel yang dipengaruhi oleh variabel independen (Wiyono, 2011: 31). Variabel terikat dalam penelitian ini adalah belanja daerah. Belanja daerah dalam penelitian ini dapat diketahui dari pos belanja daerah dalam Laporan Realisasi Anggaran Pemerintah Kabupaten Kebumen dari tahun 2009 sampai dengan tahun 2018.

2. Variabel Independen (X)

Variabel independen adalah variabel yang mempengaruhi atau menjadi sebab terjadinya perubahan terhadap variabel dependen (Wiyono,
2011: 31). Variabel independen dalam penelitian ini adalah sebagai berikut:

a. Pendapatan Asli Daerah $\left(\mathrm{X}_{1}\right)$

Pengukuran variabel Pendapatan Asli Daerah (PAD) dalam penelitian ini adalah angka realisasi Pendapatan Asli Daerah (PAD) dalam Laporan Realisasi Anggaran Pemerintah Kabupaten Kebumen dari tahun 2009 sampai dengan tahun 2018.

b. Dana Perimbangan $\left(\mathrm{X}_{2}\right)$

Dana Alokasi Umum (DAU), dan Dana Alokasi Khusus (DAK). Pengukuran variabel Dana Perimbangan dalam penelitian ini adalah penerimaan Dana Perimbangan dalam Laporan Realisasi Anggaran Pemerintah Kabupaten Kebumen dari tahun 2009 sampai dengan tahun 2018.

\section{Teknik Analisis Data}

a. Uji Normalitas

Uji normalitas bertujuan untuk menguji apakah dalam sebuah regresi, variabel bebas, variabel terikat atau keduanya mempunyai distribusi normal atau tidak (Ghozali, 2016: 163).

b. Uji Multikolinearitas

Ghozali (2011: 105) menjelaskan uji multikolinearitas bertujuan untuk mengetahui adanya korelasi linear antar variabel independen dalam model regresi. Uji multikolinearitas dapat dilihat dengan dua cara yaitu dengan melihat nilai tolerance dan Variance Inflation Factor (VIF).

c. Uji Autokorelasi

Uji autokorelasi bertujuan untuk menguji apakah dalam model regresi linear ada korelasi antara kesalahan pengganggu pada periode t dengan kesalahan pengganggu pada periode $\mathrm{t}-1$ (sebelumnya). Model regresi yang baik adalah yang terbebas dari autokorelasi.

d. Uji Heteroskedastisitas

Uji heteroskedastisitas bertujuan untuk mengetahui ada atau tidaknya penyimpangan asumsi klasik heteroskedastisitas yaitu adanya ketidaksamaan varian dari residual untuk semua pengamatan pada model regresi. Model regresi yang baik adalah yang homoskedastisitas atau tidak terjadi heteroskedastisitas (Ghozali , 2011: 139).

e. Analisis Regresi Liniar Berganda

Menurut Wijaya (2010: 25) analisis regresi linier berganda bertujuan untuk menganalisis besarnya pengaruh variabel bebas (independent) terhadap variabel terikat (dependent).

f. Uji t

Menurut Astuti (2014: 64) menjelaskan bahwa uji $\mathrm{t}$ digunakan untuk menguji pengaruh variabel independen terhadap variabel dependen. 


\section{PENGARUH PENDAPATAN ASLI DAERAH DAN DANA PERIMBANGAN TERHADAP BELANJA DAERAH PADA PEMERINTAH DAERAH KABUPATEN KEBUMEN TAHUN 2009-2018}

\section{g. Uji F}

Uji signifikansi simultan atau uji $F$ pada dasarnya menunjukkan apakah semua variabel independen atau bebas yang dimasukkan dalam model penelitian mempunyai pengaruh secara simultan atau bersama-sama terhadap variabel dependen atau terikat (Ghozali, 2011: 198).

h. Uji Koefisien Determinasi $\left(\mathrm{R}^{2}\right)$

Wijaya (2010: 26) koefisien determinasi dalam regresi berganda bertujuan untuk mengetahui berapa besar peran atau kontribusi dari beberapa variabel independen yang terdapat dalam persamaan regresi tersebut dalam menjelaskan nilai variabel dependen.

\section{HASIL DAN PEMBAHASAN}

\section{Uji Asumsi Klasik}

\section{a. Uji Normalitas}

Normal P-P Plot of Regression Standardized Residual

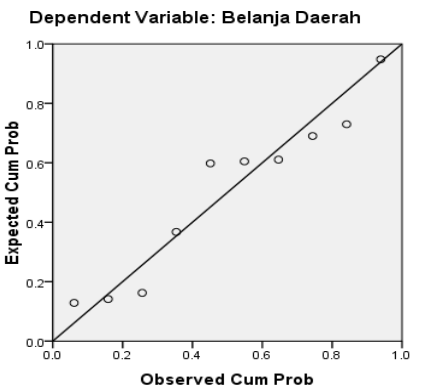

Gambar 1. Uji Normalitas

Berdasarkan gambar 1. dapat dilihat bahwa data menyebar di sekitar garis diagonal dan mengikuti arah garis diagonal, maka dapat disimpulkan bahwa model regresi tersebut memenuhi asumsi normalitas dan dapat dipakai dalam penelitian ini.

\section{b. Uji Multikolinearitas}

Tabel 1. Uji Multikolinearitas

\begin{tabular}{|c|c|c|c|}
\hline \multicolumn{4}{|c|}{ Coefficients $^{a}$} \\
\hline & & \multicolumn{2}{|c|}{ Collinearity Statistics } \\
\hline \multicolumn{2}{|c|}{ Model } & Tolerance & VIF \\
\hline \multirow[t]{3}{*}{1} & (Constant) & & \\
\hline & Pendapatan Asli Daerah & .127 & 7.850 \\
\hline & Dana Perimbangan & .127 & 7.850 \\
\hline
\end{tabular}

Berdasarkan tabel tersebut dapat dilihat bahwa semua variabel bebas telah memenuhi kriteria yaitu memiliki nilai tolerance di atas
0,10 dan memiliki nilai VIF di bawah 10. Dapat disimpulkan bahwa model regresi tersebut tidak terdapat gejala multikolinearitas atau bebas dari uji multikolinearitas.

\section{c. Uji Autokorelasi}

Tabel 2. Uji Autokorelasi Model Summary

\begin{tabular}{|c|c|c|c|c|c|}
\hline Model & $\mathrm{R}$ & $\begin{array}{c}\mathrm{R} \\
\text { Square }\end{array}$ & $\begin{array}{l}\text { Adjusted } \\
\text { R Square }\end{array}$ & $\begin{array}{l}\text { Std. Error of the } \\
\text { Estimate }\end{array}$ & $\begin{array}{l}\text { Durbin- } \\
\text { Watson }\end{array}$ \\
\hline 1 & $.988^{\mathrm{a}}$ & .976 & .969 & 110992637450.74350 & 1.661 \\
\hline \multicolumn{6}{|c|}{$\begin{array}{l}\text { a. Predictors: (Constant), Dana Perimbangan, Pendapatan Asli } \\
\text { Daerah }\end{array}$} \\
\hline \multicolumn{6}{|c|}{ b. Dependent Variable: Belanja Daerah } \\
\hline
\end{tabular}

Melalui hasil perhitungan Durbin-Watson Test (DW) dihasilkan nilai dw sebesar 1,661. Suatu uji dinyatakan bebas dari gejala autokorelasi dapat ditunjukan menggunakan kriteria hasil du $<\mathrm{dw}<4$-du. Berdasarkan DW tabel dengan jumlah data $(n=10)$ dan jumlah variabel bebas $(\mathrm{k}=2)$ diperoleh nilai $\mathrm{dl}=$ 0,6972, du= 1,6413 dan 4-du= 2,3587. Maka hasil yang diperoleh adalah $1,6413<1,661<$ 2,3587 , sehingga hasil keputusan yang didapat menunjukkan bahwa data penelitian bebas dari gejala autokorelasi.

\section{d. Uji Heteroskedastisitas}

Tabel 3. Uji Heteroskedastisitas / Glejser Coefficients $^{\mathrm{a}}$

\begin{tabular}{|c|c|c|c|}
\hline \multicolumn{2}{|c|}{ Model } & \multirow{2}{*}{$\frac{\mathrm{t}}{.054}$} & \multirow{2}{*}{$\begin{array}{l}\text { Sig. } \\
.958\end{array}$} \\
\hline 1 & (Constant) & & \\
\hline & Pendapatan Asli Daerah & .464 & .657 \\
\hline & Dana Perimbangan & .328 & .752 \\
\hline
\end{tabular}

Berdasarkan tabel 3. dapat dilihat bahwa nilai signifikan untuk kedua variabel yaitu Pendapatan Asli Daerah sebesar 0,657 dan Dana Perimbangan sebesar 0,752. Hasil tersebut menunjukkan bahwa nilai signifikan masing-masing variabel independen lebih dari 0,05 maka dapat disimpulkan tidak terjadi gejala heteroskedastisitas dalam model regresi.

\section{Analisis Regresi Linier Berganda}

Tabel 4. Analisis Regresi Linier Berganda Coefficients $^{\mathrm{a}}$

\begin{tabular}{|c|c|c|c|}
\hline & & \multicolumn{2}{|c|}{ Unstandardized Coefficients } \\
\hline \multicolumn{2}{|c|}{ Model } & $B$ & Std. Error \\
\hline \multirow[t]{3}{*}{1} & (Constant) & 332272424181.824 & 194611065355.762 \\
\hline & $\begin{array}{l}\text { Pendapatan Asli } \\
\text { Daerah }\end{array}$ & 2.559 & .769 \\
\hline & Dana Perimbangan & .749 & .267 \\
\hline
\end{tabular}

a. Dependent Variable: Belanja Daerah

Sumber: Data yang diolah, 2019 


\section{PENGARUH PENDAPATAN ASLI DAERAH DAN DANA PERIMBANGAN TERHADAP BELANJA DAERAH PADA PEMERINTAH DAERAH KABUPATEN KEBUMEN TAHUN 2009-2018}

Berdasarkan tabel 4. tesebut diperoleh hasil estimasi model dapat ditulis persamaan regresi sebagai berikut:

$\mathrm{Y}=\alpha+\mathrm{b}_{1} \mathrm{X}_{1}+\mathrm{b}_{2} \mathrm{X}_{2}+e$.

Belanja Daerah $=332.272 .424 \cdot 181,824+2,559 \mathrm{PAD}$

$$
+0,749 \mathrm{DP}+\mathrm{e}
$$

Persamaan regresi tersebut dapat diartikan sebagai berikut:

1. Nilai konstanta $(\alpha)$ sebesar 332.272.424.181,824 menyatakan bahwa pada saat variabel independen yaitu Pendapatan Asli Daerah dan Dana Perimbangan bernilai $0\left(\mathrm{X}_{1}=0\right.$ dan $\mathrm{X}_{2}=$ $0)$, maka Belanja Daerah bernilai Rp 332.272.424.181,824.

2. Nilai koefisien variabel Pendapatan Asli Daerah 2,559 menjelaskan bahwa setiap tambahan Rp 1,00 Pendapatan Asli Daerah $\left(\mathrm{X}_{1}\right)$ akan meningkatkan Belanja Daerah (Y) sebesar 2,559 atau $\mathrm{Rp} 2.559,00$ dengan asumsi variabel lain adalah tetap.

3. Nilai koefisien variabel Dana Perimbangan 0,749 menjelaskan bahwa setiap tambahan Rp 1,00 Dana Perimbangan $\left(\mathrm{X}_{2}\right)$ akan meningkatkan Belanja Daerah (Y) sebesar 0,749 atau $\mathrm{Rp}$ 749,00 dengan asumsi variabel lain adalah tetap.

\section{Uji Hipotesis}

a. Uji t

\begin{tabular}{|c|c|c|c|}
\hline & & $\mathrm{t}$ & Sig. \\
\hline \multicolumn{4}{|c|}{ Model } \\
\hline \multirow[t]{3}{*}{1} & (Constant) & 1.707 & .132 \\
\hline & Pendapatan Asli Daerah & 3.328 & .013 \\
\hline & Dana Perimbangan & 2.808 & .026 \\
\hline
\end{tabular}

1) Pengaruh Pendapatan Asli Daerah terhadap Belanja Daerah

Hasil uji t pada tabel 5. di atas, menunjukkan bahwa probabilitas signifikansi untuk variabel Pendapatan Asli Daerah $\left(\mathrm{X}_{1}\right)$ sebesar $0,013<0,05$ dan hasil perhitungan diperoleh angka $t_{\text {hitung }}$ sebesar 3,328 $>t_{\text {tabel }}$ sebesar 2,36462. Maka dapat disimpulkan bahwa hipotesis pertama diterima, artinya Pendapatan Asli Daerah berpengaruh signifikan terhadap Belanja Daerah dan diperoleh arah hubungan yang positif antara variabel Pendapatan Asli Daerah terhadap Belanja Daerah Kabupaten Kebumen. Penelitian ini sejalan dengan penelitian yang dilakukan oleh Wati dan Fajar (2017) dimana Pendapatan Asli Daerah memiliki pengaruh yang berbanding lurus dengan Belanja Daerah sehingga ketika Pendapatan Asli
Daerah mengalami peningkatan maka Belanja Daerah juga akan mengalami peningkatan ketika Dana Perimbangan tidak mengalami perubahan atau dalam kondisi tetap. Adanya Pendapatan Asli Daerah yang tinggi, maka pemerintah dapat mengalokasikan Belanja Daerahnya semaksimal mungkin. Namun, apabila Pendapatan Asli Daerah itu rendah, maka pemerintah daerah akan sulit melaksanakan Belanja Daerah yang maksimal.

2) Pengaruh Dana Perimbangan terhadap Belanja Daerah

Hasil uji t pada tabel 5. di atas, menunjukkan bahwa probabilitas signifikansi untuk variabel Dana Perimbangan $\left(\mathrm{X}_{2}\right)$ sebesar $0,026<0,05$ dan hasil perhitungan diperoleh angka $t_{\text {hitung }}$ sebesar 2,808 $>t_{\text {tabel }}$ sebesar 2,36462. Maka dapat disimpulkan bahwa hipotesis kedua diterima, artinya Dana Perimbangan berpengaruh signifikan terhadap Belanja Daerah dan diperoleh arah hubungan yang positif antara variabel Dana Perimbangan terhadap Belanja Daerah Kabupaten Kebumen. Penelitian ini sejalan dengan penelitian yang dilakukan oleh Aminus (2018) dimana Dana Perimbangan berpengaruh signifikan dengan arah positif terhadap Belanja Daerah. Hal ini menunjukkan bahwa semakin besar kontribusi Dana Perimbangan maka semakin berpengaruh terhadap besarnya alokasi dana untuk Belanja Daerah pada Kabupaten Kebumen, sehingga Kabupaten Kebumen mampu mencapai tujuan pemberian otonomi kepada daerah terutama dilakukan dengan meningkatkan pelayanan dan kesejahteraan masyakaratnya yang semakin baik pula. Dana Perimbangan merupakan dana alokasi dari pemerintah pusat yang berfungsi untuk mendorong berjalannya otonomi daerah terutama untuk daerah yang memiliki Pendapatan Asli Daerah yang relatif kecil, karena pada daerah tersebut jalannya roda pemerintahan akan bergantung pada Dana Perimbangan dari pemerintah pusat. Jika dilihat dari besarnya pengaruh Dana Perimbangan terhadap Belanja Daerah Kabupaten Kebumen, komponen Dana Perimbangan memiliki sumbangsih terbesar untuk memenuhi penerimaan pendapatan daerah Kabupaten Kebumen dalam mendanai Belanja Daerah. Pengaruh yang besar dari Dana Perimbangan terhadap Belanja Daerah ini menunjukkan bahwa pemerintah daerah Kabupaten Kebumen masih bergantung pada dana transfer dari pemerintah pusat dalam mengalokasikan Belanja Daerah. 


\section{PENGARUH PENDAPATAN ASLI DAERAH DAN DANA PERIMBANGAN TERHADAP BELANJA DAERAH PADA PEMERINTAH DAERAH KABUPATEN KEBUMEN TAHUN 2009-2018}

\section{b. Uji F}

\begin{tabular}{lllllll}
\multicolumn{8}{c}{$\begin{array}{c}\text { Tabel 6. Uji F } \\
\text { ANOVA }^{\mathbf{b}}\end{array}$} \\
\hline \multirow{2}{*}{ Model } & $\begin{array}{c}\text { Sum of } \\
\text { Squares }\end{array}$ & df & Sean & & \\
\hline 1 & Regression & $3.522 \mathrm{E} 24$ & 2 & $1.761 \mathrm{E} 24$ & 142.950 & $.000^{\mathrm{a}}$ \\
& Residual & $8.624 \mathrm{E} 22$ & 7 & $1.232 \mathrm{E} 22$ & & \\
& Total & $3.608 \mathrm{E} 24$ & 9 & & & \\
\hline
\end{tabular}

a. Predictors: (Constant), Dana Perimbangan, Pendapatan Asli Daerah

b. Dependent Variable: Belanja Daerah

Sumber: Data yang diolah, 2019

Berdasarkan tabel 6. di atas, diperoleh nilai Fhitung sebesar 142,950 dengan tingkat signifikansi $0,000<0,05$ dan $F_{\text {hitung }}$ sebesar $142,950>F_{\text {tabel }}$ sebesar 4,74 maka dapat disimpulkan bahwa hipotesis ketiga diterima, artinya secara bersama-sama variabel Pendapatan Asli Daerah (PAD) dan Dana Perimbangan berpengaruh signifikan terhadap Belanja Daerah Kabupaten Kebumen.

\section{c. Uji Koefisien Determinasi $\left(\mathbf{R}^{2}\right)$}

Tabel 7. Uji Koefisien Determinasi Model Summary ${ }^{\mathrm{b}}$

\begin{tabular}{|c|c|c|c|c|}
\hline \multicolumn{5}{|c|}{ Model Summary ${ }^{\mathrm{b}}$} \\
\hline Model & $\mathrm{R}$ & R Square & $\begin{array}{l}\text { Adjusted R } \\
\text { Square }\end{array}$ & $\begin{array}{l}\text { Std. Error of the } \\
\text { Estimate }\end{array}$ \\
\hline 1 & $.988^{\mathrm{a}}$ & .976 & & $\begin{array}{r}110992637450.74 \\
350\end{array}$ \\
\hline
\end{tabular}

a. Predictors: (Constant), Dana Perimbangan, Pendapatan Asli Daerah

b. Dependent Variable: Belanja Daerah

Sumber: Data yang diolah, 2019

Berdasarkan tabel 7. hasil tampilan output Model Summary di atas menunjukkan bahwa besarnya Adjusted R Square adalah 0,969, hal ini berarti bahwa $96,9 \%$ yang menunjukkan bahwa Belanja Daerah dipengaruhi oleh variabel Pendapatan Asli Daerah dan Dana Perimbangan. Sedangkan sisanya sebesar $3,1 \%$ dipengaruhi oleh variabel lain yang belum diteliti dalam penelitian ini.

\section{KESIMPULAN DAN SARAN}

\section{Kesimpulan}

Berdasarkan hasil penelitian mengenai pengaruh Pendapatan Asli Daerah dan Dana Perimbangan terhadap Belanja Daerah pada Pemerintah Daerah Kabupaten Kebumen pada tahun 2009-2018, dapat ditarik kesimpulan sebagai berikut:

1. Variabel Pendapatan Asli Daerah $\left(\mathrm{X}_{1}\right)$ memiliki nilai Sig. sebesar $0,013<0,05$ dan hasil perhitungan diperoleh angka $t_{\text {hitung }}$ sebesar 3,328 $>t_{\text {tabel }}$ sebesar 2,36462 menunjukkan bahwa variabel Pendapatan
Asli Daerah berpengaruh signifikan dan memiliki arah positif terhadap Belanja Daerah.

2. Variabel Dana Perimbangan $\left(\mathrm{X}_{2}\right)$ memiliki nilai Sig. sebesar 0,026 $<0,05$ dan hasil perhitungan diperoleh angka $t_{\text {hitung }}$ sebesar 2,808 $>t_{\text {tabel }}$ sebesar 2,36462 menunjukkan bahwa variabel Dana Perimbangan berpengaruh signifikan dan memiliki arah positif terhadap Belanja Daerah.

3. Hasil uji F (simultan) juga menunjukkan bahwa secara bersama-sama variabel Pendapatan Asli Daerah dan Dana Perimbangan berpengaruh signifikan terhadap Belanja Daerah pada Pemerintah Daerah Kabupaten Kebumen. Karena memiliki nilai $F_{\text {hitung }}$ sebesar 142,950 $>F_{\text {tabel }}$ sebesar 4,74 dengan nilai tingkat signifikansi $0,000<0,05$.

4. Berdasarkan hasil analisis regresi linear berganda diperoleh hasil uji Koefisien Determinasi $\left(\mathrm{R}^{2}\right)$ diperoleh nilai sebesar 0,969 artinya 96,9\% variabel Belanja Daerah dipengaruhi oleh variabel Pendapatan Asli Daerah dan Dana Perimbangan. Sedangkan sisanya sebesar $3,1 \%$ dipengaruhi oleh variabel lain yang belum diteliti dalam penelitian ini. Hasil ini membuktikan bahwa variabel Belanja Daerah pada Pemerintah Daerah Kabupaten Kebumen belum bisa sepenuhnya dijelaskan oleh variabel Pendapatan Asli Daerah dan Dana Perimbangan karena nilainya masih dibawah $100 \%$.

\section{Saran}

Berdasarkan kesimpulan yang telah dipaparkan di atas, maka penulis memberi saran sebagai berikut:

\section{Bagi Pemerintah Daerah Kabupaten Kebumen}

a. Untuk meningkatkan alokasi Belanja Daerah maka pemerintah daerah diharapkan terus menggali sumber-sumber Pendapatan Asli Daerah dengan secara intensif dan aktif.

b. Pemerintah Daerah Kabupaten Kebumen seharusnya lebih bisa menyesuaikan pengeluaran Belanja Daerah dengan pendapatan yang diterima.

c. Pemerintah daerah diharapkan dapat memanfaatkan dana yang diperoleh dari Pendapatan Asli Daerah dan Dana Perimbangan untuk membangun infrastruktur publik yang memang dibutuhkan oleh masyarakat serta meningkatkan saran dan prasarana umum guna meningkatkan kesejahteraan masyarakat.

\section{Bagi Penelitian Selanjutnya}

a. Untuk peneliti selanjutnya diharapkan penelitian ini dapat menjadi acuan untuk melakukan penelitian berikutnya dengan menambah jumlah populasi dan sampel yang lebih diperluas pada tingkat provinsi atau nasional sehingga hasilnya menjadi lebih baik.

b. Untuk peneliti selanjutnya disarankan untuk menambah variabel independen lain dalam penerimaan pendapatan lain yang diduga dapat mempengaruhi Belanja Daerah berupa variabel 


\section{PENGARUH PENDAPATAN ASLI DAERAH DAN DANA PERIMBANGAN TERHADAP BELANJA DAERAH PADA PEMERINTAH DAERAH KABUPATEN KEBUMEN TAHUN 2009-2018}

keuangan seperti Lain-Lain Pendapatan Daerah yang Sah dan SiLPA maupun variabel nonkeuangan seperti kebijakan pemerintah dan kondisi makro ekonomi.

\section{DAFTAR PUSTAKA}

Aminus, Rahmi. 2018. Pengaruh Pendapatan Asli Daerah dan Dana Perimbangan terhadap Belanja Daerah Kabupaten Ogan Ilir. Jurnal Ekonomi Global Masa Kini Mandiri 9(1): 47-55.

Astuti. 2014. Statistika Teori dan Aplikasi. Erlangga. Jakarta.

Banga, W. 2017. Administrasi Keuangan Negara dan Daerah: Konsep, Teori, dan Fenomena di Era Otonomi Daerah. Ghalia Indonesia. Bogor.

Ghozali, I. 2011. Aplikasi Analisis Multivariate dengan Program IBM SPSS 19. Edisi Kelima. Badan Penerbitan Universitas Diponegoro. Semarang.

2016. Aplikasi Analisis Multivariatif dengan Program IBM SPSS 19. Cetakan VIII. Badan Penerbit Universitas Diponegoro. Semarang.

Halim, A. 2001. Definisi Keuangan Daerah: Akuntansi Keuangan Daerah. Edisi Ketiga. Salemba Empat. Jakarta.

Syarifin, P. dan Jubaedah, D. 2005. Pemerintah Daerah di Indonesia. CV Pustaka Setia. Bandung.

Undang-Undang Republik Indonesia Nomor 33 Tahun 2004 Perimbangan Keuangan Antara Pemerintah Pusat dan Pemerintah Daerah. 15 Oktober 2004.

Nomor 9 Tahun 2015 Pemerintahan Daerah. 18 Maret 2015. Jakarta.

Wati M.R. dan C. M. Fajar. 2017. Pengaruh Pendapatan Asli Daerah dan Dana Perimbangan Terhadap Belanja Daerah Kota Bandung. Jurnal Kajian Akuntansi 1(1): 59-72.
Widjaja, A. W. 2002. Otonomi Daerah dan Daerah Otonomi. Raja Grafindo Persada. Jakarta.

Wijaya, T. 2010. Analisis Multivariat. Universitas Atma Jaya. Yogyakarta.

Wiyono, G. 2011. 3 In One: Merancang Penelitian Bisnis Dengan Alat Analisis SPSS 17.0 \& SmartPLS 2.0. Edisi 1. UPP STIM YKPN. Yogyakarta.

Wulandari, Y. 2014. Pengaruh Dana Bagi Hasil Terhadap Belanja Daerah pada Kabupaten dan Kota di Indonesia. Skripsi. Fakultas Ekonomi Universitas Negeri Padang. Padang.

Yani, Ahmad. 2008. Hubungan Keuangan Antara Pemerintah Pusat dan Daerah. Grafindo. Jakarta. 